\begin{tabular}{c} 
Volume and Issues Obtainable at Center for Sustainability Research and Consultancy \\
Responsible Education, Learning and Teaching in Emerging Economies \\
ISSN: 2708-4310 \& (E): 2708-4183 \\
Volume 3: No.1, June 2021 \\
CSRᄃ \\
Journal homepage: www.publishing.globalcsrc.org/relate \\
\hline
\end{tabular}

\title{
Clinical Legal Education and its Implication on Legal Education System in Pakistan: Challenges and Prospects
}

Rashida Zahoor, College of Law, University of Sahiwal, Pakistan

*Naureen Akhtar, Gillani Law College, Bahauddin Zakariya University Multan, Pakistan

Rao Imran Habib, Gillani Law College, Bahauddin Zakariya University Multan, Pakistan

*Corresponding author's email: naureen.akhtar@bzu.eu.pk

\begin{tabular}{l}
\hline ARTICLE DETAILS \\
\hline History \\
Revised format: May 2021 \\
Available Online: Jun 2021
\end{tabular}

Keywords

Legal Education System, Legal Profession, Law Clinic, Legal Reforms, Pakistan.

JEL Classification A20, A21

\begin{abstract}
Purpose: To improve the standard of legal education, legal clinic is one of the modern techniques. Legal profession is a noble profession as it is considered to uphold the justice in a society. A law student may be taught in a such manner that he must be well equipped with professional skills.

Methodology: Previous studies have been discussed with the help of current data for thorough review of challenges in Pakistan.
\end{abstract}

Findings: In Pakistan, legal education system needs many reforms in order to produce good lawyers. Without professional skills and practical knowledge; a law graduate is unable to utilize his degree in a proper manner. To attain such professional skills; legal clinics are good approach. Where students may be able to seek practical knowledge and also helping the deserving people. LL. B degree awarding institutions shall make it possible to provide clinical legal education. Law clinics must be installed in law faculties where the experts may be available to educate students.

Implications: In this paper, the importance of law clinic is discussed and certain issues are highlighted which are prevailing in current legal education system of Pakistan. Study can help out policy makers to identify challenges and to overcome these issues they can formulate different strategies.

(C) 2021 The authors, under a Creative Commons Attribution-

NonCommercial 4.0

Recommended citation: Zahoor, R., Akhtar, N. and Habib, R. I. (2021). Clinical Legal Education and its Implications on Legal Education System: Challenges and Prospects. Responsible Education, Learning and Teaching in Emerging Economies, 3 (1), 15-26.

\section{Introduction}

Legal education has a great impact on society. As a law graduate after completing his education has to become an advocate or a judge. Thus, the effect of legal education is significant on Bar and Bench. Similarly, it is also necessary to get good knowledge of law during law schooling in order to practice other tasks in a society. Like, it is essential for lawmaking, law-implementation, good 
governance, and administration of justice in a society, corporate consultancy, alternate dispute resolutions and much more. Legal profession demands certain special skills from Lawyers and Judges to excel in their field and to do justice in a society (Rev. \& 1913, n.d.). They have a responsibility to give justice to the people and to make them aware about certain social crimes as well as the values of a society. It is possible only with the true implementation of law. Such true application of law not only promote the rule of law but also bring democracy and financial stability in a state (Bradney, 1998).

The want of better legal education and special reforms to train the law students to meet with daily needs of a society is unavoidable. To improve the quality of legal education; some necessary actions are required to taken. Like how many colleges are there in a country to cater the needs of a society to give legal education. Then, who is the legal coach there and what is taught in law syllabus. Further, what measures are taken to train the law students in practical knowledge as these skills are necessary to practice law in their professional life? It is also the observed that the syllabus and law faculty; both are insufficient in Pakistani law colleges; especially in private sectors (Osama Siddique, n.d.). Keeping in view the role of a law student in a society it is required to review and update the existing legal syllabus and to introduce the reforms in law faculties to implement these changes.

Legal profession is dependent upon the special expertise and skills of a law student. This expertise will help him to practice the law not only with confidence and honesty but also assist him to deal with its different branches. But this level of skills may be attained only with good training and updated legal education. As the law has been divided into many branches such as civil law, criminal law, corporate law, family law, cyber law, international law human rights and so on. Every branch needs some special skill. Such skills may be given to law students to give speedy remedy to the society. Without a better education system in legal domain, it is not possible to get good lawyers or good judges in Pakistan legal system. Therefore, the existing system of legal education in Pakistan may be replaced by an advanced legal schooling. So that the improvements may be brought in Pakistani legal system and needed may be attained in legal profession (Mehar \& Saghir M, 2020).

The main issue in existing Pakistani legal education system is the deficiency of case study method. As compared to the developed nations, Pakistan is far behind to implement the practical approach in its legal education system. This deficiency makes the students handicap to others in their drafting and pleading approaches. Law mooting is another teaching methodology to equip the law students with practical knowledge which is also not practiced properly during study at law colleges. During the late $19^{\text {th }}$ and middle of $20^{\text {th }}$ centuries the United States (U.S.) adopted various legal training methods including clinical legal education (Osama Siddique, 2010).

However, a few numbers of law colleges are trying to provide the practical knowledge to its law students. These colleges are offering non-credit courses to train the students in certain legal skills. But these students are not sufficient to cater the needs of a society. Further, there is no uniform pattern to equip these students with specific practical knowledge to make them able to practice law after passing out from Law College. They don't have skills to draft the technical pleadings and to present their pleas before courts in expert ways. Further, analytical approach is also deficient in these law students which are required to hold opinions and to convince court. Moreover, they don't have the ability to imagine, analyze, and construct their analogy on a logical and rational basis. Law colleges must make arrangements in their employees to improve these abilities in their students. In this way, their professional and moral responsibilities will prevent them to impart from building critical legal instruction to younger lawyers. As a result, law graduates shall improve their 'abilities' by studying on the job or by working with those who have these abilities. Sometimes, these students move abroad to seek good methodologies in legal 
field. In all these situations, the basic legal skills may be provided to law students by making them available in Pakistan law colleges (Osama Siddique, 2013).

\section{Legal Education in Pakistan: Challenges}

In Pakistan legal education is not seeking such attention which is necessary for legal profession. Institutions which are providing legal education are ignoring certain values to equip the law students with professional skills. Professional bodies are also overlooking their duty to train the young lawyers or to facilitate them expert seniors for becoming proficient in practical knowledge. In this way universities and bar councils collectively neglected and affected the values of legal schooling. Hence, there is a grave need to deal with this situation. It requires major adjustments to make it task-oriented and consistent with global requirements. Legal schooling is typically offered by both- public and private universities- which follow the educational program and requirements set forth by the Higher Education Commission (HEC) in consultation with the Pakistan Bar Council (PBC); an legal association which manages the law profession and legal education at country level(Shah, Balasingam, \& Dhanapal, 2018).

In Pakistan, there are roughly fifteen public sector law schools/faculties which are right now providing legal education (Sial, n.d.). There are more than seventy private law schools/faculties connected with public sector institutions. Apart from this, certain law degree awarding institutions collaborate with overseas universities to offer split degree programs. The HEC's role is to act as a facilitator, bringing together all public and private institutions, as well as contributors to the PBC's Legal Education Committee, to verify and revise the curriculum every three years. The National Curriculum Review Committee is in charge of carrying out this task (NCRC). The NCRC's (Law) recommendations are then discussed in a joint meeting of representatives from universities and members of the PBC (Legal Education Committee). These suggestions are then forwarded to institutions in order for the newly developed curriculum to be implemented. The mandate of the Higher Education Commission (HEC) is outlined in Section 10 of the Higher Education Commission Ordinance of 2002("Osama Siddique, "Law in PracticeThe Lahore District... - Google Scholar,” n.d.).

It also prescribes situations for how higher education institutions should carry out their duties. The PBC is constantly working to improve the requirements for legal education. According to Sections 13(j) and (k) of the Legal Practitioners and Bar Councils Act of 1973, the PBC's functions include the promotion of law education as well as the establishment of certain parameters for law education in consultation with the colleges. It also recognizes certain universities that meet the desired standards of legal education and whose L.L.B degree will be considered for enrolment as an advocate. Curriculum reviews for legal education are not wellexecuted and far-reaching. Most institutions overlook the significance of these meetings and send their junior nominees to take part in these discussions (Osama Siddique, n.d.).

The application mechanisms are also left to the colleges and universities' discretion. At this point, the HEC has no authority because universities are independent bodies in their functions. Furthermore, as autonomous bodies, universities are solely responsible for internal control. Besides that, revision of the curriculum does not entail revision of the syllabus alone. Curriculum review includes curriculum and course material instruction, such as content definition, teaching instrumentation, and lecture syllabus material. It also includes the professional grooming and training of instructors/tutors in order to better educate students. It is an essential exercise which deals with key questions and a way to tackle them in a better education system that is characterized by diversity and fairness. It is also accompanied by the awarding of scholarships for higher education of faculty that are appropriate to meet a state's social, cultural, and financial desires (Mehar \& Saghir M, 2020). 
After discussing the HEC and PBC functions, the functions of colleges and universities must also be briefly discussed. Miss administration, irresponsiveness of academics, politics, teacher pressure groups, directors and college students and professional unethical behaviour anomalies the functioning of universities across the public sector. Many universities are misused to tackle these problems and subsequently to regulate the frameworks. An administration which is not able to pay due interest and cannot fulfill its obligations has to perform a key task to improve legal education which is hardly possible. There are even no permanent law professors at law schools in many institutions. Besides the poor administration of these law schools, the teaching job lies in the hands of practitioners who are unable to do justice to legal education due to their professional commitments. Academics in the law faculty of universities and colleges, have a poor performance in their respective universities and are deeply motivated by their 'academic environment'(O Siddique, 2013). The system of law education in Pakistan has been destroyed by this exercise. There are also not properly structured higher degrees in law and research activities. L.L.M. degree in law is offered by only a few public sector universities. Furthermore, students and teachers do not have a good quality of research. The culture of research in the field of law somehow doesn't grow properly. A few people are participating in research work, which is done at various organizations by law graduates. In particular, the changes within society have led to a globalization which has brought many changes to the education sector.

To examine the declining legal education standards, important steps have to be taken nationwide. It is proposed that a Commission for Legal Education Reform be set up. The establishment of a 'Commission for Legal Education Reform,' as it monitors the operations of law schools, is honestly vital. It will look at cultures and current trends in various countries and assess them. The commission's proposals can be submitted before all stakeholders. It can develop an agreement on legal education reforms. In addition, the dual control by HEC and PBC simultaneously is also a major obstacle in improving law education standards. It is also important to remove dual control, the HEC and PBC, in order to ensure that legal training is in line with the needs of society. In HEC and universities; the PBC should not interfere. Legal education is a challenge for universities, and with the assistance of the HEC, the universities should be authorized to prescribe many guides.

It is suggested that each Law Faculty and Law College should be consisted upon a curriculum evaluation committee constituted by senior members of their Study Boards. This could replace the existing NCRC working with the HEC. The new NCRC may be a body that will be able to satisfy the requirements of the profession of law and deliberating on new schemes / techniques to meet the needs of the global community. The committee may also prescribe minimum guidelines for all students of law. The rest may be left to the university's wishes and needs. PBC can be given the vitality to recognize and identify the law degree. After getting certain law subjects together with practical skills and other necessary interdisciplinary courses to meet the needs of society, an LL.B degree of five years has to be awarded. Therefore, apart from the main legal issues, a pupil has to take supporting subjects such as sociology, economics, logic, political, technical expertise, philosophical records and the like. This interdisciplinary method truly improves the law training requirements and leads to better law graduates who can meet the market requirements.

The improvement of legal education depends also on the legal instructors' terms of service. In general, law teachers receive insufficient income from universities and other law schools by comparing legal education to other disciplines. Legislation is a professional subject, however, and cannot be treated in common with various education disciplines. So, with this pay package and benefits, it is possible to obtain a specialist chemist, botanist, historian or political scientist but it is truly hard to employ a strong lawyer as an equal package deal. 


\section{Clinical Legal Education}

Clinical education is defined as the training of law students in a such way that they may be equipped with certain skills and techniques. These skills and techniques make them proficient to deal with challenges during practice. In this type of learning students go through a process and become acquainted with an experience of doing things which a lawyer should do while pleading and presenting his client before a court. Clinical methods are taught to students to prepare a case and to make arguments for the pursue of justice. Like other subjects, it is also a practical knowledge of being a good advocate. After getting degree; the student shall not be needed to join a senior attorney for the learning of practical knowledge. In this method students experience the situation of real world which they shall face after completing their education. Therefore, in clinical method a student is capable of understanding practical approach towards his profession as well as the demands of a society to implement the justice.

Clinics are where law students meddle in and learn how law and legal professionals can handle these requirements in the local community. Clinical training is also very important in comparison to conventional teachers. Clinical training as well happens at the door. Clinicians learn facts on the ground so they have to be tackled very much. They spend most of their years in training staff and the bar. In essence, legal clinical education is a cross-cutting problem. If done with pedagogical integrity, it deepens the excellence of training, and helps to lay a foundation for law students to hold with them a greater sense of professional commitment to public welfare. Meanwhile, law clinics often provide needed aids to the community beyond the study room on different legal problems. Ultimately, clinics immerse the legal academy both the college students and instructors within the universe as actors, not only observers.

The word 'clinical education' has a deceiving impact. Many would think that it is something that is only performed in the subject of medicine which is however not a lie. Clinical schooling is one of the illustrations of medical training where students are often given possibilities to practice medication. Technically the phrase 'clinical education' is not strictly restrained to the remedy or medicine based-aptitudes related training. Clinical education refers to applications or brief guides which offer specialists-in-schooling with sensible and skills-orientated preparation in the supervision of a professional practitioner. This short article focuses upon the opportunity of clinical schooling within the domain of law whereby the law students will be having enough possibility to get professional education at the same time as finishing their law schooling. As it may be a smart alternative to a mandatory six-month internship that is taken up after the scholar has finished his/her LLB degree and is ready to apply for a license to appear in the courts.

As to the opportunity of law training, the solution is satisfactory. There exists a vast area known as clinical legal education and in most advanced countries legal training has a few critical components regarding legal schooling and law clinic. Most of such clinics work free of charge in public interest litigation and social welfare.

\section{How Clinical Legal Education Works?}

Clinical legal schooling is essentially an element and basic idea of law curricula taught in a college. The idea is to have a law clinic facility inside the law school or college for law pupils in the supervision of a coach. The law clinic will be controlled by a faculty member who would also be a practicing lawyer too. In this clinic, the law students shall be engaged in different tasks by various positions like associates and internees at law chambers. Here they could get an opportunity to work with actual clients and aggrieved parties and face real troubles of legal profession. This hiring shall be used as an apparatus to analyze the techniques used in the exercise of law and their relation to the academic aspect of the law. This workout in the legal clinic gives law students adequate possibility to engage them, in the practice of law and to enhance their abilities in practice. 
Interestingly, the law clinics can be general in their scope or they may be specified. There are different law clinics that provide awareness on special aspects of law. These spheres can be decided according to the various factors like family disputes or employment matters, or according to the expertise of the legal faculty and coach. However, the law clinic may refuse to accept any case if it looks against the justice. The ultimate standards should be the academic worth of the case, the law points concerned in it, its appropriateness that whether students of the law clinic will be capable of handling the case or not, and also the public services elements of it and its impact on community.

Although at the time of launching a Law Clinic, questions may arise regarding the nature of the cases which may be dealt in it. It is also considered that whether there may be any opportunity of actually receiving a possibility to represent a person in Court. Once the case is admitted by the law clinic, students are then assigned the case in the supervision of a skilled attorney cum faculty member. The scholar is trained to research well on the matter in issue both directly or significantly. Through various discussions each with the customer and the faculty supervisor, the pupil is then engaged in real time case preparation. It is also pertinent to mention that law clinic can have a high-quality impact on each the education of the law college students and the human rights of the vulnerable, ultimately, making a gateway for the poor to reach to justice.

\section{Impact of Law Clinic on Legal Education}

The significance of clinical law schooling cannot be ignored. As early as in 1930s, the American law schools started to look into new methods to equip their law students with new techniques and skills. It also included the modernization of curricula and pedagogy ways to introducing more students with courts and their skills training in a law clinic. It is going without announcing that the practical legal experience of designing official memorandums and trial briefs trains in very effective manner than written presentation of cases. The clinical work in all respects provides supports to the prevailing strategies of legal education, and in this way make the law students to grab the required skills to become successful in practice. The basic question however is whether or not the law college shall try to bridge the gap present between law school teaching methods and actual needs for which the young advocated want to exercise the law practice correctly in courts(Author, Azam, \& Azam, 2005).

Although the educators of law acknowledge the insufficiency of present curricula to achieve certain skills for practice, they avoid the objection by stating that this education is now useful in practice, and that it must wait until a student completes his degree and applies for his admittance to the Bar. Certainly, no clinic at a law college can educate the skills of practice in its entirety; however, it should also to be understood that no law university purports to educate the whole of substantive law and procedures. The law curriculum is designed to teach students in basic ideas of law, and one would confess instructional inadequacy if it's assumed that substantive principles inside the art and approach of exercise can't likewise be made the subject of law college instructions and teachings.

Furthermore, the education received at a legal clinic associated with a law faculty links the distance that a graduate might face during the duration of the transitional period between graduating and interning in the practical law field. Moreover, the chamber or workplace is not an academic institution. Whether engaged in a profession or enterprise, the legal professionals in a law office are usually involved with dealing the matters of their clients in lieu of some economic reward. The few younger attorneys who find opportunity of practice in large law offices may additionally acquire some legal education along with training but such schooling is for the advantage of the workplace. It is a sink or swim technique, with a ready substitute that whether the scholar lawyer fails to meet the expectations or become successful. The function of the 
younger lawyer in such an office is specialized, and he may never be able to win in his professional training by acquiring all skills of practice ("A Ahmad, The Challenge of Islamic Law, Journal of... - Google Scholar," n.d.). This struggle promotes the philosophy that legal clinics are a good deal that is strongly needed in the Pakistani systems of legal education and training.

\section{Global Perspective of Clinical Legal Education}

There are three main essentials which highlight the need of clinical education in legal profession. The first element is related to the want of practical skills in the field of law. Without practical knowledge, a law student is not able to meet the requirements of legal profession. Second element is about social responsibility to fulfill the requirements of justice. It is the duty of a law practitioner to be acquainted with the practical issues of legal education so that the justice may be applied properly. Third element is the duty of law teachers to ensure the joining of world movement to join clinical methods to improve the quality of legal education. There are only few countries which are trying to impose the clinical education in legal domain. Different NGO's, lawyers, teachers and judges are taking part in the move of clinical legal training (Bloch, n.d.).

Now we may examine these three components. These three elements are working together to ensure the maximums of legal education reforms. Such as because of global movement and effort of different NGO's as well law practitioners this need has become a universal demand. Every country is getting focused to install new methods of case study in legal education. For this purpose, the websites and curriculum of different nations may be reviewed. Most of the countries have shifted towards practical approaches in order to strengthen their students. Like USA, UK, Africa, Russia, China, Netherlands and India is participating prominent role in the international move for clinical methods in legal profession. In this regard, many conferences are held in these countries to exchange the thoughts for improvement in clinical methodology as well as to implement these methods. Many conferences are also held by the Global Alliance for Justice Education (GAJE)(“N. R. Madhava Menon, "The Transformation of Indian... - Google Scholar," n.d.). These conferences are attended by very prominent number professionals (Bloch, n.d.).

The concept of "Clinical Education" and "Clinical Curriculum" is different from nation to nation. It may be dependent upon various values of a society. Further, the meaning of clinical education is also influenced by the needs of a society. Therefore, cultural and political as well economic factors are also important in the move of clinical legal training. It is quite possible that the curriculum of a law school in a society may be different from the other law school of a different society(Educ. \& 2009, n.d.).

However, there are some positive key features in these clinics around the world: First and foremost, a professional training assignment for the law clinic will be assigned without delay. International clinics emphasize two curriculum objectives to prepare students for legal work, one of which is not adequately stressed in traditional law school curricula: professional skills development and the award of public responsibility and social justice professionals. The method is linked to a secondary function. The clinical coaching approach is founded on a focus on experiential knowledge. Clinical training helps students to get knowledge with the help of experiments rather than to cram knowledge in class rooms. Traditional methods are limited only to the extent of lecture delivery in class rooms (Mehar \& Saghir M, 2020).Finally, the reforms for clinical law form a part of a broader endeavors to extend the curriculum, implement revolutionary techniques of coaching and teach social justice to law professionals. At the same time, the creation of a clinical training in various legal schools in different countries is an achievement on the worldwide level of legal training today. Wherever legal education was provided, a struggle was conducted there. With its concentration on new subjects, the law school clinics have by no means been a smooth promotion of social motion and are used through dramatically specific 
training methods (Krishnan, n.d.).

Clinical legal education is gaining popularity in today's education system. It is attracting the law schools to train their students in professional way. It is enhancing responsibility in students. Institutions are striving to produce the best law graduates who may be the nominees of them. Keeping these circumstances in viewing, China, Nigeria, Africa and Russia are trying to attract the law students at universal level. These countries are trying to put their best to attain a visible improvement in clinical aspect of law profession. Such type of efforts shall not only ensure the quality of legal education but also enhance the social justice at international level. The law syllabus is also updated to protect the moral values and natural justice in a society. Law schools are updated with a law clinic where the expert instructors are hired to equip the law graduates with clinical skills. Such practice set up the examples for other countries. These principles are also adopted USA, Australia and European countries. Community cases are picked to teach the students.

In this global movement the clinical legal education is combined with clinical legal aid. In this phenomenon cases are selected from the surrounding community. Social justice is also involved in this practice. The needy and poor people are also encouraged to seek justice by participating in this regard. Students are also encouraged to help the poor without any remuneration. In this way clinical education turns into clinical aid. Teachers and instructors are motivated in this movement to teach their students with social justice values. These practices are more common in China and Africa. Later on, these practices were also travelled to other countries like America and United Kingdom. Legal clinic with the idea of legal aid to deserving society is more common in developing stares (Bloch, n.d.). The idea of global movement for planning legal education in clinical perspectives fulfilled in two ways. Firstly, the national as well as international needs are kept in mind to promote justice and social development. Secondly, the experts are invited to train the law students in clinical methods. For this resolve, associations are built with mutual cooperation of different international communities. In these associations Students and law professionals work together to attain the goal of clinical legal education.

Let's look at a couple of prominent examples. "Street Law is a legal education that developed and accelerated its impact in the international legal Community through a strong component of social justice"("Roger Burridge, "Six Propositions for Legal Education... - Google Scholar," n.d.). The "First Street Law" in the USA establishes the traditional version by which a law-based social project and challenge introduces socially applicable legal education. The first step into the law clinic was for law students at Georgetown University to learn about their rights in law schools in Washington DC. Street Law has over time been able to access the Legal Curriculum by means of an educational project involving the college administration and teachers in professional skills and values in the preparation and promotion of public interest law students and practice. The "Street Law faculty" were the pioneers of the clinical movement in the United States. However, over the last two decades, "Street Law" has played an active role in the development of allies in various parts of the world, including some that were unexpected. We can see this distinctive characteristic of the evolution of street law within "South Africa". Since apartheid ended, "street law in South Africa" highlighted the role of law literacy as a particularly effective tool for social change while also establishing the capacity of law students to sponsor awareness on basic civil rights. "Street Law clinics" in a world of clinical law teaching have raised openness of and increased the importance of legal projects for the international community, even while carrying out primarily regional projects. Various forms of legal initiatives benefited from the links and links established by international law education during the implementation of their social justice initiative. These initiatives are not always externally international; they can certainly benefit from the clinical network around the world to achieve their local objectives. 
Almost any clinical project, if viewed in this light, can take on an international dimension: legal projects focusing on family issues, environmental issues, or just about any other aspect of the legal problem that can become the subject of legal clinics. Global perspectives of legal proceedings are more favorable aspect of clinical law training in this movement. The subject of international interest is easily managing at universal level. Law students shall be more confident to deal with human rights issues and other kinds of international law as compared to domestic law. This approach will help them to work together (Jeong, n.d.). Law students shall learn more about the territory and jurisdiction issues at global level. Law instructors may also be more helping to train a student in those legal issues which are not limited to one country. In this way the clinical methods may be applied on human rights issues or in some trade cases. This may be resulted in universal achievement of justice.

The basic objective is to educate and provide pupils with legal knowledge as well as a sense of social responsibility. Various branches of international law may be addressed in this regard. As trade law, immigration law, environmental law, health ethics and much more. In these areas of law international legal community may work together to exchange their knowledge and to address different issues in legal profession (Trubek \& Popper, n.d.). For example, students usually perform service in an immigration center; they simply come from another country. The global legal aspect involves crossing borders and cultures while at the same time representing a local individual. So, if the customer seeks refugee status, or wants to increase his or her knowledge, the students handling a case of immigration will want to seek legal advice from another foreign country or develop information. These types of clinics have prospered with private and specialist linkages between cross-border clinicians and areas which could no longer be available without clinical education under international law (Bradney, 1998).

Ultimately the purpose of global legal education along with clinical methods has been attained. However, it took a couple of years to implement this idea of clinical legal training. But now it has been adopted by many countries in the world. Law schools have updated their curriculum and syllabus to impose clinical methodology in legal education. Although this movement is yet to be adopted by a large number of law faculties. There is a need to forward this movement across the globe without discrimination of any society. As it is necessary to attain the global peace and justice.

Despite the fact that structural and content changes are unavoidable, law clinics around the world provide professional knowledge in specialized aptitudes and principles, focusing on crucial areas of expert and public concern not addressed by traditional regulations and university curricula. As clinicians around the world recognize the commitment to reorient law schooling to teach lawyers about social justice, in particular smart and socially responsible law students as a critical issue for the social justice assignment of clinical legal training, there should also be a collective sense of determination within the clinical employer (Rev. \& 1913, n.d.). Peggy Maisel points out three requirements which she believes the clinicians around the world have broad shared: increased legal access for formerly unrepresented companies; the increase of the apparatus of legal education, which ensures the fate of the legal professionals that they have the expertise, capacities and values to help the complex problems of the world. It is also important for an international clinical agenda to be carried out. But efforts to strengthen the worldwide clinical motion must not jeopardize clinicians' costs to undermine informal networking and minimize current and growing national and regional legal experts' essential role. Significant advancements in clinical schooling have really been made through the participation of clinicians at conferences, workshops, meetings and seminars at regional and global level. Clinical law tutoring is currently an overall move, and in this worldwide municipality there is an emergent international clinical association. Certain projects are worked together by world clinicians to enhance the clinical approach of law students. 


\section{Future of Clinical Legal Education in Pakistan's Legal Education System}

Law clinics provide a platform to the students where they can come out from their lecture halls and step into the actual and real law world. By representing actual existing law clients; students can begin to reap a deeper expertise of how legal doctrines or theories perform function within the law world. This in turn, encourages them to polish their professional as well as legal talents. While being the representative of a client and resolving a legal dispute, students can also come across the troubles faced by the legal structure where doctrines or theories ended up being misapplied or misfit. This would offer a completely unique attitude to a law student who nonetheless will be deeply connected to the idea and doctrine and yet will be capable of noticing their flaws when carried out. This in the long run will encourage the students of law to view the legal education from the perspective of justice. The facility of legal clinic as part of clinical schooling instructs students about the actual functioning of the legal mechanism thereby inculcating in them the value and responsibility of public service (Author et al., 2005).

It is particularly ideal that the law schooling reforms in Pakistan be balanced with the introduction of clinical legal education in the law colleges in Pakistan as it would now not only enhance the practical talents but also gives the experience of responsibilities for a law student. By helping clients, handling with their legal disputes in addition to social troubles, the students can be inspired to have a fruitful and problem-solving perspective of legal framework.

\section{Recommendations}

It is said that the activities of the clinic can have an excellent effect on both the training of the law college students and the legal in addition to human rights of the neglected persons, in the long run, providing a gateway for the poor to gain access to justice without any financial burden on their pockets. Although Law colleges in Pakistan have a repute and educational status accomplished by a series of globally acknowledged activities achieved by the various eminent law colleges of the country and their students. However, the establishment of a legal clinic is very much needed in the scenario of present time to meet the needs of a society and to enhance the abilities of law students. The aim is to address the major social problems including women's rights, labour rights, rights of the children and most significantly rights of the poor and vulnerable groups.

Unfortunately, legal education and clinical training has been approached by the institutions within the premises of classrooms in Pakistan. The intended Law Clinic proposes to rigorously educate law students through exposing them to practical issues for getting access justice, which will motivate the law students to consider the real problems within the legal world. The superficial loss of deeper pondering behind the need of legal education and clinical schooling in Pakistan has led the legal career undeveloped in a sustained style. The formation of clinical programs in law colleges can remove this issue by performing an important function in restoring lawyers as effective representatives of social progress. This will equip college students with the vital vocational competences so that they may acquire the desired social change.

Moreover, presently, there may be little proximity between legal profession and law faculty in Pakistan. This proximity is enormously relevant if law schooling is having any influence on law practice in courts. The clinical schooling may also beautify this proximity by presenting the specified discussion forum for communication between students and law practitioners. The students as aforementioned could be exposed to court proceedings; steps concerned in a civil/criminal lawsuits and traditional legal practices in a court.

\section{Conclusion}

Finally, it is better and safe to mention that law clinics are a much-wanted reform for law 
schooling taught in classrooms in Pakistan. It performs a completely unique position in exposing students to social injustice in a society. By presenting assistance in the form of pro-bono cases, law college students analyze the significance of legal professionals resolving clients' legal issues. Students may even get a possibility to refine their talents and decorate their Curriculum Vitae (CV) for his or her destiny in employability at market. Further, the students will even obtain professional behavior that will be helpful in law practice and proceedings of courts. They need to be reminded that 'justice' itself is not something that emerges ipso facto from the prevailing legal machine. It is felt that with law clinics, a significant if not a variety of influence, may be made to bring change to the present circumstances of Pakistan.

\section{References}

A Ahmad, The Challenge of Islamic law, Journal of... - Google Scholar. (n.d.). Retrieved June 19 , 2021 ,

from https://scholar.google.com/scholar?hl=en\&as_sdt=0\%2C5\&q=A+Ahmad\%2C+The+Challe nge+of+Islamic+law\%2C+Journal+of+Legal+Education $\% 2 \mathrm{C}+\mathrm{Vol} .+55 \% 2 \mathrm{C}+\% 282005 \% 29$ $\% 2 \mathrm{C}+\mathrm{p} 475 . \& \mathrm{btnG}=$

Author, B., Azam, M. M., \& Azam, M. M. (2005). Association of American Law Schools Reforming Legal Education in. In Source: Journal of Legal Education (Vol. 55). Retrieved from https://www.jstor.org/stable/42893940

Bloch, F. S. (n.d.). EDUCATION AND LAW REVIEW Número 4. Abril-septiembre 2011 Fecha de entrada: 29-09-2011 Fecha de aceptación.

Bradney, A. (1998). Law as a Parasitic Discipline. Journal of Law and Society, 25(1), 71-84. https://doi.org/10.1111/1467-6478.00080

Educ., L. D.-J. L., \& 2009, undefined. (n.d.). Reforming Indian legal education: Linking research and teaching. In HeinOnline. from www.education.nic.in/cd50years/n/75/7Y/Toc.htm

Jeong, Y.-C. K. (n.d.). (155) Korean Legal Education for the Age of Professionalism: Suggestions for More Concerted Curricula. In HeinOnline. Retrieved from http://info.leet.or.kr/.

Krishnan, J. K. (n.d.). Professor Kingsfield Goes to Delhi: American Academics, the Ford Foundation, and the Development of Legal Education in India. In academic.oup.com. Retrieved from https://academic.oup.com/ajlh/article/46/4/447/1777943

Mehar, \& Saghir M. (2020). Bridging the Growing Disjunction Between Legal Education and Practice in Pakistan. Retrieved from https://repository.library.northeastern.edu/files/neu:m045rv37b/fulltext.pdf

N. R. Madhava Menon, "The Transformation of Indian... - Google Scholar. (n.d.). Retrieved June 19 , 2021 from https://scholar.google.com/scholar?hl=en\&as_sdt=2005\&sciodt=0\%2C5\&cites $=523172147$ $2557704685 \&$ scipsc $=\& q=N .+$ R. + Madhava + Menon\%2C $+\% 22$ The+Transformation+of + Indi an+Legal+Education $\% 3 \mathrm{~A}+\mathrm{A}+\mathrm{Blue}+$ Paper\%22\%2C+Harvard+Law+School+Program $+\mathrm{On}+\mathrm{t}$ he+Legal+Profession\%2C+\%282012\%29.\&btnG=

Osama Siddique, "Law in Practice- The Lahore District... - Google Scholar. (n.d.). Retrieved June 19, 2021, from https://scholar.google.com/scholar?hl=en\&as_sdt=0\%2C5\&q=Osama+Siddique $\% 2 \mathrm{C}+\% 22 \mathrm{~L}$ aw+in+Practice-+The+Lahore+District+Courts+Litigants+Survey+\%282010$+2011 \% 29 \% 22 \% 2 \mathrm{C}+$ Development+Policy+Research+Centre\%2C+Working+Paper+June+ $\% 282010 \% 29 \% 2 \mathrm{C}+\mathrm{pp} 94-95 . \& \mathrm{btnG}=$

Rev., M. G.-L., \& 1913, undefined. (n.d.). Legal Education: Academical and Professional. HeinOnline. Retrieved from https://heinonline.org/hol-cgibin/get_pdf.cgi?handle=hein.journals/lqr29\&section=43

Roger Burridge, "Six Propositions for Legal Education... - Google Scholar. (n.d.). Retrieved June 19 , 
https://scholar.google.com/scholar?hl=en\&as_sdt=2005\&sciodt=0\%2C5\&cites $=595077701$ 926751610\&scipsc $=\& q=$ Roger + Burridge $\% 2 \mathrm{C}+\% 22 \mathrm{Six}+$ Propositions + for+Legal+Education + in+Local+and+Global+Development $\% 22 \% 2 \mathrm{C}+$ Journal+of+legal+Education $\% 2 \mathrm{C}+\mathrm{Vol} .+55$ \&btnG $=$

S. Freeland, "Educating lawyers for transitional... - Google Scholar. (n.d.). Retrieved June 19, 2021 , from https://scholar.google.com/scholar?hl=en\&as_sdt=0\%2C5\&q=S.+Freeland $\% 2 \mathrm{C}+\% 22 \mathrm{Educa}$ ting+lawyers+for+transitional+challenges $\% 22 \% 2 \mathrm{C} \& b \operatorname{tnG}=$

Shah, S. A., Balasingam, U., \& Dhanapal, S. (2018). Legal Education in Pakistan: An Overview Legal Education in Pakistan View project. Researchgate.Net. https://doi.org/10.31436/iiumlj.v26i2.380

Sial, A. Q. (n.d.). Designing Legal Education to Support Social Evolution in Pakistan. In South Asian Studies A Research Journal of South Asian Studies (Vol. 24). Retrieved from http://citeseerx.ist.psu.edu/viewdoc/download?doi=10.1.1.1057.1986\&rep=rep1\&type=pdf

Siddique, O. (2010). DPRC Working Paper. Retrieved from https://www.academia.edu/download/30993117/DPRC-WP4-Siddique.pdf

Siddique, O. (2013). Pakistan's experience with formal law: an alien justice. Retrieved from https://books.google.com/books?hl=en\&lr=\&id=ur_Q9SnMDfgC\&oi=fnd\&pg=PR10\&dq= Osama+Siddique,+Pakistan\%27s+Experience+with+Formal+Law:+An+Alien+Justice,+Ca mbridge+University+Press+(2013).\&ots=rx3ZbHzprH\&sig=v_rKDWwv5SYnwimWSfBq_ 94LhSU

Siddique, Osama. (n.d.). Legal Education in Pakistan: The Domination of Practitioners and the "Critically Endangered" Academic. In HeinOnline. Retrieved from http://www.

Trubek, D. M., \& Popper, K. (n.d.). The Construction and Deconstruction of a Disputes-Focused Approach: An Afterward. In JSTOR. Retrieved from https://www.jstor.org/stable/3053510 